\title{
Cytogenetic markers as tools in delimiting species of the highly diverse Neotropical fish Bryconamericus (Characiformes: Characidae)
}

\author{
Anahiê Bortoncello Prestes ${ }^{1}$, Aline Nardelli², Leonardo Marcel Paiz ${ }^{2}$, \\ Mariane Gavazzoni ${ }^{1}$ and Vladimir Pavan Margarido ${ }^{1,2}$
}

Bryconamericus is a highly diverse group of characid fishes, being cytogenetic a valuable tool for the delimitation of species. Bryconamericus aff. iheringii (Upper Uruguay/Lower Paraná), B. coeruleus (Upper Paraná), B. cf. ecai e B. cf. eigenmanni (Upper Uruguay) were studied cytogenetically, and presented $2 \mathrm{n}=52$ chromosomes, with interpopulational/interspecific variation of karyotype and fundamental number. Heterochromatin was evidenced in pericentromeric, telomeric and interstitial regions, and it was shown to be an important cytogenetic marker. Single nucleolar organizing regions (NORs) were found in $B$. cf. eigenmanni, B. cf. ecai and $B$. aff. iheringii (Lower Paraná), and multiple in $B$. aff. iheringii (Upper Uruguay) and $B$. coeruleus, with occurrence of two patterns for the first species, and three for the second. The 5S/18S rDNA-FISH confirmed the location of the NORs and showed single 5S rDNA cistrons only in B. aff. iheringii (Lower Paraná), evidencing the dispersion of both genes, often co-located, in the karyotype of the others species. The data of this work contribute for the delimitation of the species of the genus. Co-localization of ribosomal genes may represent a plesiomorphic condition for the group, and their dispersion suggest the occurrence of duplication, pseudogeneization and transposition events mediated by mobile genetic elements.

Keywords: Chromosome rearrangements, Co-localization, Cytotaxonomy, Cytosystematics, Intra and interspecific variation, Ribosomal genes.

Bryconamericus é um grupo altamente diverso de caracídeos, sendo a citogenética uma valiosa ferramenta para a delimitação de espécies. Bryconamericus aff. iheringii (Alto Uruguai/Baixo Paraná), B. coeruleus (Alto Paraná), B. cf. ecai e B. cf. eigenmanni (Alto Uruguai) foram estudados citogeneticamente, e apresentaram $2 \mathrm{n}=52$ cromossomos, com variação interpopulacional/interespecífica de cariótipo e número fundamental (NF). Heterocromatinas foram evidenciadas nas regiões pericentromérica, telomérica e intersticial, e mostrou-se um importante marcador citogenético. Regiões organizadores de nuclcéolos (RONs) simples foram encontradas em B. cf. eigenmanni, B. cf. ecai e $B$. aff. iheringii (Baixo Paraná), e múltiplas em $B$. aff. iheringii (Alto Uruguai) e em B. coeruleus, com a ocorrência de dois padrões de localização para a primeira espécie, e três para a segunda. A FISH-DNAr 5S/18S confirmou a localização das RONs e mostrou cístrons simples de DNAr 5S apenas em B. aff. iheringii (Baixo Paraná), evidenciando a dispersão de ambos os genes, muitas vezes co-localizados, no cariótipo das demais espécies. Os dados deste trabalho contribuem para a delimitação das espécies do gênero. A colocalização dos genes ribossomais pode representar uma condição plesiomórfica para o grupo, e sua dispersão sugere a ocorrência de eventos de duplicação, pseudogenização e transposição mediada por elementos genéticos móveis.

Palavras-chave: Citossistemática, Citotaxonomia, Co-localização, Genes ribossomais, Rearranjos cromossômicos, Variação intra e interespecífica.

\section{Introduction}

Bryconamericus Eigenmann (1907) is a diverse group with approximately 60 species (Fricke et al., 2019) distributed by the cis and trans Andean basins from
Panama in Central America to northern Argentina in South America (Jerep, Shibatta, 2017; Mirande, 2018). They are small fish, known to have morphologically similar species and high taxonomic and phylogenetic complexity.

\footnotetext{
${ }^{1}$ Departamento de Biologia, Universidade Estadual de Maringá (UEM), Avenida Colombo, 5790, 87020-900 Maringá, PR, Brazil. (ABP) anahie94@gmail.com, @https://orcid.org/0000-0003-2949-2478; (MG) marianegavazzoni@gmail.com, Dhttps://orcid.org/0000-00034546-2420; (VPM) vladimir.margarido@unioeste.br (corresponding author), (Dhttps://orcid.org/0000-0002-0823-6646

${ }^{2}$ Centro de Ciências Biológicas e Saúde, Universidade Estadual do Oeste do Paraná (UNIOESTE), Rua Universitária, 2069, 85819-110 Cascavel, PR, Brazil. (AN) alinenardellibio@gmail.com, Ohttps://orcid.org/0000-0002-9523-1359; (LMP) leonardo_paiz@hotmail.com, (Dhttps://orcid.org/0000-0002-4761-8321
} 
Despite the efforts, the phylogeny of Bryconamericus is quite controversial and currently no monophyletism evidence has been found. The genus was first recorded in Tetragonopterinae (Géry, 1977), after was classified as incertae sedis in Characidae (Lima et al., 2003), and in the same year it changed to "clade A" sensu Malabarba, Weitzman (2003). Using various morphological and osteological characters, Mirande (2009) reorganized incertae sedis genera into previously identified clades, including Bryconamericus, which became the Stevardiinae clade. Javonillo et al. (2010) kept Bryconamericus in incertae sedis within the so-called "clade A", which also contained two subfamilies of Characidae (Glandulocaudinae and Stevardiinae) and other incertae sedis genera. Mirande (2010, 2018), Oliveira et al. (2011) and Thomaz et al. (2015) propose Bryconamericus as a polyphyletic group within Stevardiinae, but only the phylogeny of Mirande (2018) restricts the genus to the Diapomini tribe.

Even with its representativeness in Stevardiinae and the high number of phylogenetic studies, few Bryconamericus species have been the target of cytogenetic and molecular studies. The data obtained are mostly restricted to the Upper Paraná River basin, where four species of this genus: B. exodon Eigenmann (1907) (type-species), B. iheringii (Boulenger, 1887), B. turiuba Langeani, Lucena, Pedrini \& Tarelho-Pereira, 2005 and B. coeruleus Jerep \& Shibatta, 2017, quoted above as $B$. aff. iheringii and found in the basins of the Ivaí, Piquiri and Tibagi rivers, syntopic with other Stevardiinae.

Cytogenetic studies in trans-Andean Bryconamericus species evidenced the maintenance of the diploid number of 52 chromosomes, with inter and intraspecific divergences regarding the karyotype formula and the fundamental number (FN) (Paintner-Marques et al., 2002a, 2002b, 2003; Capistano et al., 2008; Portela-Castro et al., 2008; among others). Likewise, other cytogenetic characters were shown to be variable, such as the distribution of heterochromatin and the number and location of the nucleolar organizer regions (NORs) (Eberhardt et al., 2012; Santos et al., 2012, 2017; Silva et al., 2014), with variation even among individuals of the same population. In relation to 5S rDNA ribosomal genes, the data are restricted to only four species, revealing simple cistrons in $B$. cf. iheringii (Piscor et al., 2013) and Bryconamericus sp. (Santos et al., 2017, Cambutá River), and multiple cistrons with intraspecific variation in B. turiuba (Piscor et al., 2013), B. ecai and Bryconamericus sp. (Vermelho stream) (Santos et al., 2017), being that in some cytotypes these genes presented syntenic to $18 \mathrm{~S}$ rDNA genes.

Due to the high complexity chromosomal and phylogenetic found in Bryconamericus, and the absence of broad studies of phylogeny including cytogenetic data, this work uses basic cytogenetic techniques (Giemsa, C-banding and AgNORs) and molecular (FISH with probes from the $5 \mathrm{~S}$ and $18 \mathrm{~S}$ rDNA). These techniques will be useful as markers in the differentiation of four Bryconamericus species, from the Upper Uruguay River, Upper Paraná River and Lower Iguaçu River. In this way, the present study aimed to expand the cytogenetic data for the genus in order to find for markers that may aid in the differentiation of these species and in the understanding of phylogenetic relationships into the group.

\section{Material and Methods}

Specimens of four species of Bryconamericus were collected: 4 males and 5 females of $B$. aff. iheringii from the Ijuí River, Upper Uruguay River basin (State of Rio Grande do Sul); 1 male and 3 females of $B$. aff. iheringii from the Iguaçu River, Lower Iguaçu River basin (State of Paraná); 13 males and 4 females of $B$. coeruleus of the Piquiri River, Upper Paraná River basin (State of Paraná); 1 male and 5 females of $B$. cf. ecai, and male of $B$. cf. eigenmanni from the Biguá Stream, Upper Uruguay River basin (State of Santa Catarina) (Tab. 1).

All specimens were anesthetized and euthanized by an overdose of clove oil (Griffiths, 2000), and deposited in the Coleção Ictiológica do Núcleo de Pesquisas em Limnologia, Ictiologia e Aquicultura (NUPELIA) of the Universidade Estadual de Maringá (UEM), Brazil. The chromosomal preparations followed the methodology proposed by Bertollo et al. (1978), and the NORs were evidenced by impregnation by silver nitrate, according to Howell, Black (1980). The C-banding was used to determine the heterochromatic regions following the technique proposed by Sumner (1972), with modifications suggested by Lui et al. (2012). Physical mapping of the 5S rDNA and 18S rDNA was carried out by fluorescence in situ hybridization (FISH) according to Pinkel et al. (1986) and modifications suggested by Margarido, Moreira-Filho (2008), using DNA probes obtained from Megaleporinus elongatus (Valenciennes, 1850) (Martins, Galetti-Junior, 1999) and from Prochilodus argenteus Spix \& Agassiz, 1829 (Hatanaka, Galetti-Junior, 2004), respectively. Probes were labeled by nick translation method with digoxigenin11-dUTP (5S rDNA) and biotin-16-dUTP (18S rDNA) (Roche $\left.{ }^{\circledR}\right)$. Detection of signals was performed with antidigoxigenin-rhodamine (Roche $\left.{ }^{\circledR}\right)$ for probe of $5 \mathrm{~S}$ rDNA and amplified avidin-FITC with biotinylated antiavidin (Sigma-Aldrich) for probe of $18 \mathrm{~S}$ rDNA, with the chromosomes counterstained with 4',6-diamidino2-phenylindole (DAPI, $50 \mu \mathrm{g} / \mathrm{mL}$ ). Metaphases were photographed using a BX 61 epifluorescence microscope, coupled with Olympus DP 72 digital camera (Olympus America, Inc.) with the Olympus cellSens software 2.1 for image processing. The homologous chromosomes were paired and classified in accordance to the ratio of arms (q/p) in metacentric (m), submetacentric (sm), subtelocentric (st) and acrocentric (a), as proposed by Levan et al. (1964). The fundamental number (FN) was calculated considering the chromosomes ' $\mathrm{m}$ ', 'sm' and 'st' as having two arms, and the 'a' chromosomes as having only one chromosomal arm. 
Table 1. Bryconamericus species collected and their collection sites. $\hat{\sigma}=$ Males, $q=$ Females, NUP $=$ voucher numbers of the Coleção Ictiológica do Nupélia.

\begin{tabular}{|c|c|c|c|c|c|c|}
\hline Species & Locality & Basin & Geographic Coordinates & $\hat{0}$ & q & NUP \\
\hline Bryconamericus aff. iheringii & Ijuí River & Upper Uruguai River & $28^{\circ} 18^{\prime} 06.3^{\prime \prime} \mathrm{S} / 53^{\circ} 53^{\prime} 33.6^{\prime \prime} \mathrm{W}$ & 4 & 5 & 15737 \\
\hline Bryconamericus aff. iheringii & Iguaçu River & Lower Iguaçu River & $25^{\circ} 37^{\prime} 13.20^{\prime \prime} \mathrm{S} / 54^{\circ} 23^{\prime} 29.20^{\prime \prime} \mathrm{W}$ & 1 & 3 & 14930 \\
\hline Bryconamericus coeruleus & Piquiri River & Upper Paraná River & $24^{\circ} 56^{\prime} 54^{\prime \prime} \mathrm{S} / 52^{\circ} 35^{\prime} 49^{\prime \prime} \mathrm{W}$ & 13 & 4 & 5923 \\
\hline Bryconamericus cf. ecai & Bigua Stream & Upper Uruguai River & $26^{\circ} 53^{\prime} 22.5^{\prime \prime} \mathrm{S} / 53^{\circ} 23^{\prime} 03.1^{\prime \prime} \mathrm{W}$ & 1 & 5 & 21293 \\
\hline Bryconamericus cf. eigenmanni & Bigua Stream & Upper Uruguai River & $26^{\circ} 53^{\prime} 22.5^{\prime \prime} \mathrm{S} / 53^{\circ} 23^{\prime} 03.1^{\prime \prime} \mathrm{W}$ & 1 & - & 21294 \\
\hline
\end{tabular}

\section{Results}

The results are presented in Figs. 1-3, and summarized in Tab. 2 and Fig. 4. They are described below.

Bryconamericus aff. iheringii (Ijuí River). The diploid number observed was 52 chromosomes $(10 \mathrm{~m}+16 \mathrm{sm}+$ $14 \mathrm{st}+12 \mathrm{a}, \mathrm{FN}=92$ ). Silver impregnation revealed the presence of two NOR localization patterns: pattern I -5 individuals who exhibited markings in the terminal region of the short arm of the pair of acrocentric chromosomes 26 , and in one of the chromosomes of the acrocentric pair 25; and pattern II -4 individuals who exhibited the third marking on the first chromosome of the acrocentric pair 21 (Fig. 1a, boxes). The location of AgNORs was confirmed by $18 \mathrm{~S}$ rDNA-FISH for the two patterns (Fig. 3a). The $\mathrm{C}$-banding showed heterochromatin in the pericentromeric region of almost all chromosomes, as well as conspicuous blocks associated with NORs, pale blocks in both arms of the metacentric pair 01 , and subterminal/terminal heterochromatin in the long arm of the acrocentric pair 22 (Fig. 2a). It should be noted that pattern II presented a higher number of chromosomes with pericentromeric heterochromatic regions when compared to the pattern I (Fig. 4a). 5S rDNA-FISH showed simple cistrons in the terminal region of the short arm of the pair of acrocentric chromosomes 26, syntenic to the cistrons of $18 \mathrm{~S}$ rDNA, for the individuals who presented the pattern II; and four cistrons of this gene for the individuals that presented the I pattern, three being syntenics to the $18 \mathrm{~S}$ rDNA cistrons (pair of acrocentric chromosomes 25 and first chromosome of the acrocentric pair 21), and the other located in the terminal region of the short arm of the first chromosome of the submetacentric pair 7 (Fig. 3a).

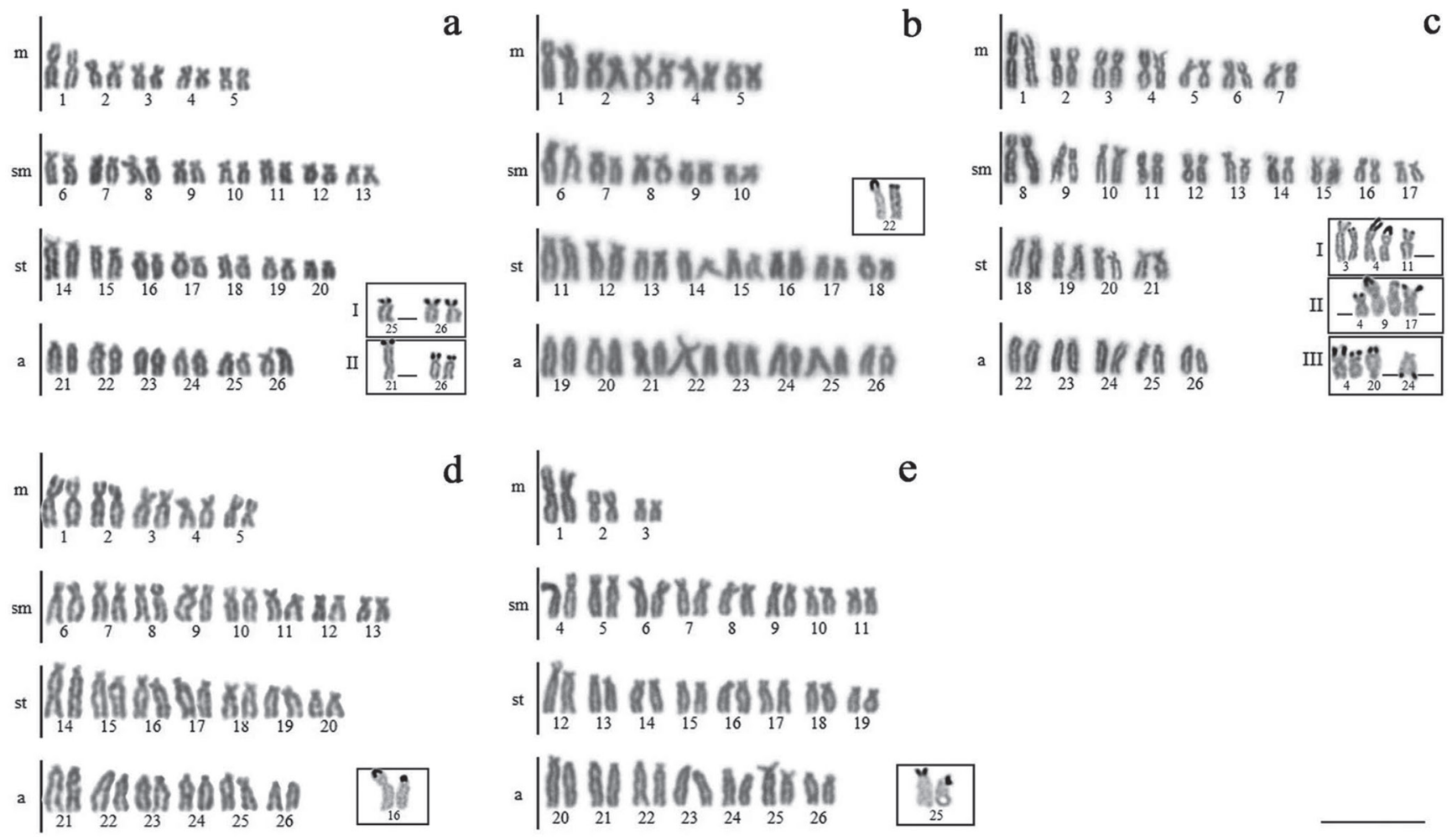

Fig. 1. Karyotypes arranged from Giemsa-stained chromosomes. Pairs of the AgNORs are in the boxes. a. Bryconamericus aff. iheringii (Ijuí River) - box I: pattern I; box II: pattern II; b. $B$. aff. iheringii (Iguaçu River); c. $B$. coeruleus - box I: pattern I; box II: pattern II; box III: pattern III; d. B. cf. ecai; e. B. cf. eigenmanni. Scales bar $=10 \mu \mathrm{m}$. 


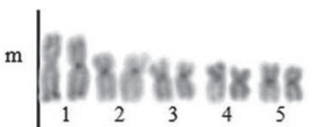

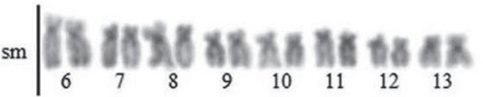

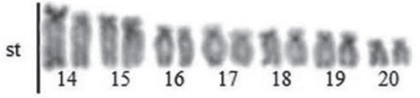

a

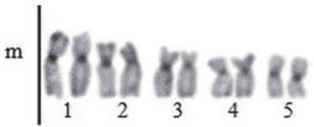

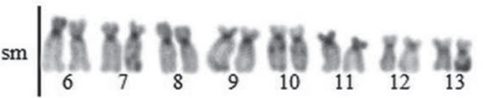

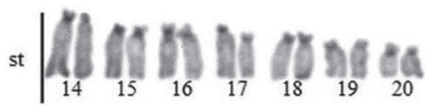

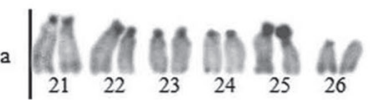

a
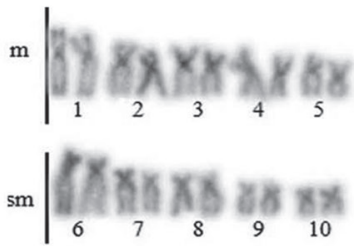

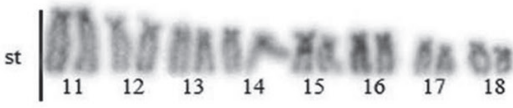

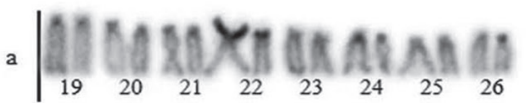

d $\left.\left.\right|_{1}\right|_{2} x_{3}$

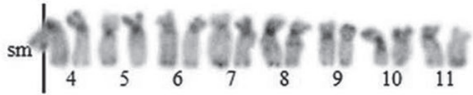

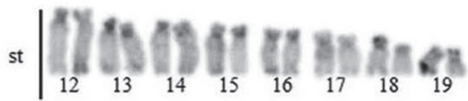

a
C

b

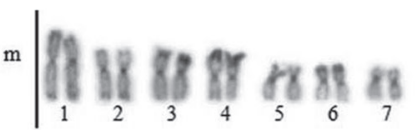

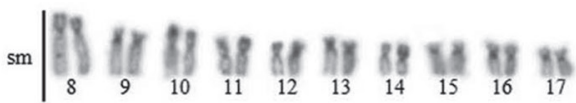

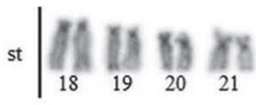

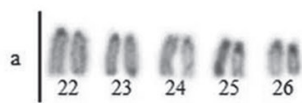

e

Fig. 2. Karyotypes arranged from C-banded chromosomes. a. Bryconamericus aff. iheringii (Ijuí River, pattern II); b. B. aff. iheringii (Iguaçu River); c. B. coeruleus (pattern II); d. B. cf. ecai; e. B. cf. eigenmanni. Scales bar $=10 \mu \mathrm{m}$.

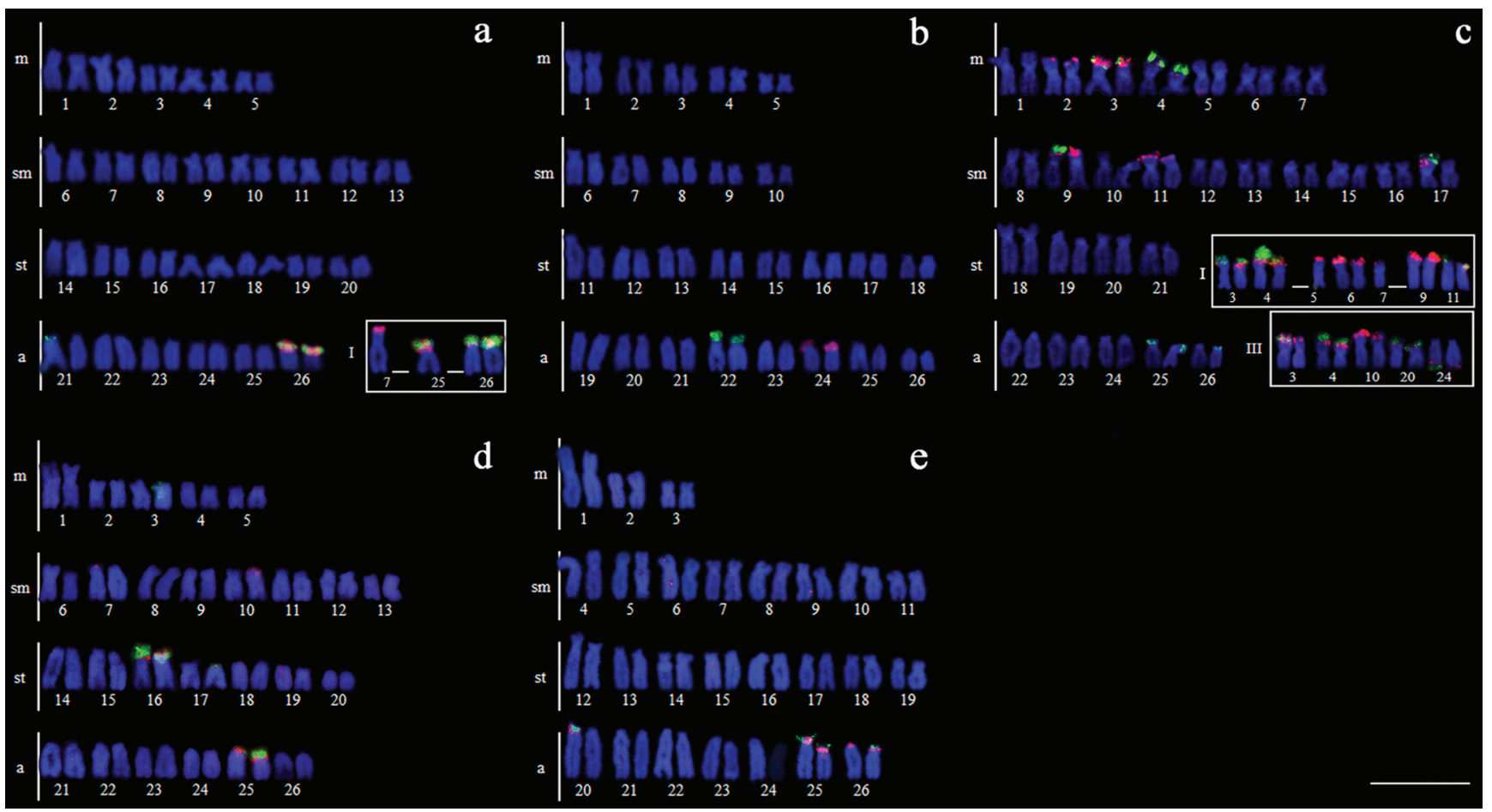

Fig. 3. Karyotypes after FISH with $5 \mathrm{~S}$ rDNA probes (red) and $18 \mathrm{~S}$ rDNA probe (green). In the boxes, the intra-population variations that represent distinct patterns of localization of ribosomal genes. a. Bryconamericus aff. iheringii (Ijuí River, pattern II) - box I: pattern I; b. B. aff. iheringii (Iguaçu River); c. B. coeruleus (pattern II) - box I: pattern I; box III: pattern III; d. B. cf. ecai; e. B. cf. eigenmanni. Scales bar $=10 \mu \mathrm{m}$. 
Bryconamericus aff. iheringii (Iguaçu River). The diploid number observed was 52 chromosomes $(10 \mathrm{~m}$ $+10 \mathrm{sm}+16 \mathrm{st}+16 \mathrm{a}, \mathrm{FN}=88)$, and the presence of single NORs, located in the terminal region of the short arm of the pair of acrocentric chromosomes 22 (Fig. 1b), and confirmed by $18 \mathrm{~S}$ rDNA-FISH (Fig. 3b). The C-banding showed heterochromatin in the pericentromeric region of almost all chromosomes, in addition to revealing conspicuous blocks in the terminal region of the pairs of chromosomes corresponding to NORs, pale blocks in both arms of the metacentric pair 01 , and interstitial heterochromatin in the long arm of the pair of subtelocentric chromosomes 15 (Fig. 2b). The $5 \mathrm{~S}$ rDNA-FISH showed single cistrons, located in the terminal region of the short arm of the pair of acrocentric chromosomes 24 .

Bryconamericus coeruleus (Piquiri River). The diploid number observed was 52 chromosomes $(14 \mathrm{~m}+20 \mathrm{sm}+$ $8 \mathrm{st}+10 \mathrm{a}, \mathrm{FN}=94)$. At least three patterns of NORs were found for this population, being denominated as I (4 individuals), II (8 individuals) and III (5 individuals). The pattern I was characterized by the presence of at least five bearing chromosomes these regions (metacentric pairs 3 and 4, and one of the chromosomes of the subtelocentric pair 11 - Fig. 1c, box I), while the other two patterns presented four bearing chromosomes, which differed from each other (pair of submetaccentric chromosomes 9, and one of the chromosomes of the metacentric 4 and submetacentric 17 pairs to the pattern II, and in the pair of metacentric chromosomes 4 and one of the chromosomes pairs of the subtelocentric 20 and acrocentric 24 - long arm, in this case - for pattern III (Fig. 1c, boxes II and III, respectively)). The C-banding showed heterochromatin in the pericentromeric region of most chromosomes, and terminal pairs in addition to those corresponding to NORs, such as pairs 1 and 2 (both arms), 3, 6, 10, 11 (only on short arm) and 23 (only on long arm) of the individuals who presented the pattern I (Fig. 2c), differing from pattern II where only the metacentric chromosome pair 1 exhibited terminal heterochromatin. This pattern was also different due to the presence of a pericentromeric/ interstitial band in the long arm of the acrocentric chromosomes 26 pair (Fig. 4c-II). The pattern III showed heterochromatic regions similar to those of pattern I, except for heterochromatin associated with NORs, whose pairs of bearing chromosomes differed between the two patterns (Fig. 4c-III). The 18S rDNA-FISH confirmed the location of the NORs and showed an extra cistron for the pattern I, five extra cistrons for the pattern II and two extra cistrons for the pattern III, totaling six, ten and six $18 \mathrm{~S}$ rDNA sites, respectively (Fig. 3c). The 5S rDNAFISH revealed a pattern of dispersion of this gene in the karyotype, with intrapopulational variation of 10 to 11 cistrons, all restricted to subterminal/terminal region of the short arm, except for an individual who presented pattern III where a cistron of $5 \mathrm{~S}$ rDNA was evidenced in the subterminal region of the long arm of the pair of acrocentric chromosomes 24. The three patterns exhibited various colocalized 5S/18S rDNA cistrons. There were four syntenic chromosomes in pattern I (both homologues of pairs 3 and 4), six in pattern II (both homologues of pairs 3 and 4 , and one chromosome of pairs 9 and 17) and six in pattern III (both homologues of pairs 4 and 20, and one chromosome of pairs 3 and 24), plus six cistrons of 5S rDNA for pattern I and four for patterns II and III, totaling ten, eleven and ten cistrons of this gene, respectively (Figs. 3c, 4c).

Bryconamericus cf. ecai (Biguá Stream). The diploid number observed was 52 chromosomes $(10 \mathrm{~m}+16 \mathrm{sm}+$ $14 \mathrm{st}+12 \mathrm{a}, \mathrm{FN}=92$ ), and the presence of single NORs located in the terminal region of the subtelocentric chromosomes 16 pair (Fig. 1d). The C-banding revealed heterochromatin in the pericentromeric region of most chromosomes, interstitial in the long arm of the pair of submetacentric chromosomes 10 , and terminal in the pairs of metacentric chromosomes 1 and 2 (both arms), submetacentric pair 10, subtelocentric pairs 14, 15 and 16 , and acrocentric pairs 21, 24 and 26 (only in the long arm for all). In the pair of acrocentric chromosomes 25 the short arm was entire heterochromatic, unlike the pair of NORs, which in this species did not present heavily marked heterochromatic bands (Fig. 2d). The $18 \mathrm{~S}$ rDNA-FISH confirmed the localization of the NORs, and evidenced extra cistrons in the terminal region of the short arm of the acrocentric chromosomes 25 pair, in both cases syntenic to 5S rDNA cistrons (Figs. 3d, 4d).

Bryconamericus cf. eigenmanni (Biguá Stream). The diploid number observed was 52 chromosomes $(6 \mathrm{~m}+$ $16 \mathrm{sm}+16 \mathrm{st}+14 \mathrm{a}, \mathrm{FN}=90$ ), and the presence of simple NORs located in the terminal region of the acrocentric chromosomes 25 pair (Fig. 1e). The C-banding revealed heterochromatin in the pericentromeric region of most chromosomes, interstitial in the long arm of the submetacentric chromosomes 8 and acrocentric 26 pairs, and terminal on the short arm of submetacentric pairs 4, 9 and 10 and subtelocentric pair 19, and in the long arm of submetacentric pairs $4,5,6,7,8$ and 11 , subtelocentric pair 16, and acrocentric pairs 20,21, 23 and 26. The chromosomes pair bearing the NORs had the fully heterochromatic short arm (Figs. 2e, 4e). The 18S rDNA-FISH confirmed the localization of the NORs and showed two extra cistons in the short arm of one acrocentric chromosomes of the pairs 20 and 26 . The $5 \mathrm{~S}$ rDNA-FISH showed 5 cistrons of this gene, four of them syntenic to $18 \mathrm{~S}$ rDNA genes, and the other located on the short arm of the first chromosome of the acrocentric pair 26 (Figs. 3e, 4e). 
$\mathbf{a}$

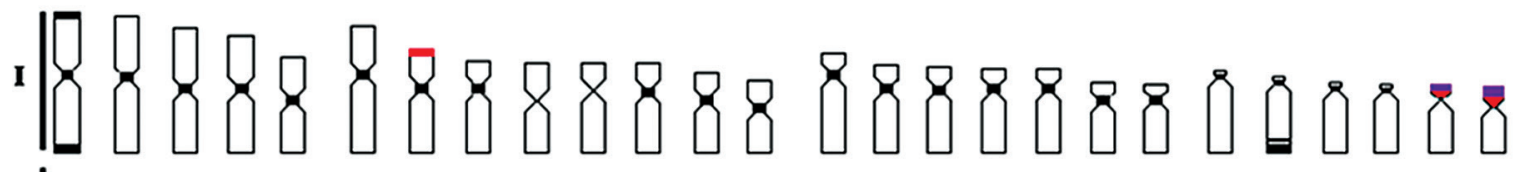

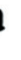

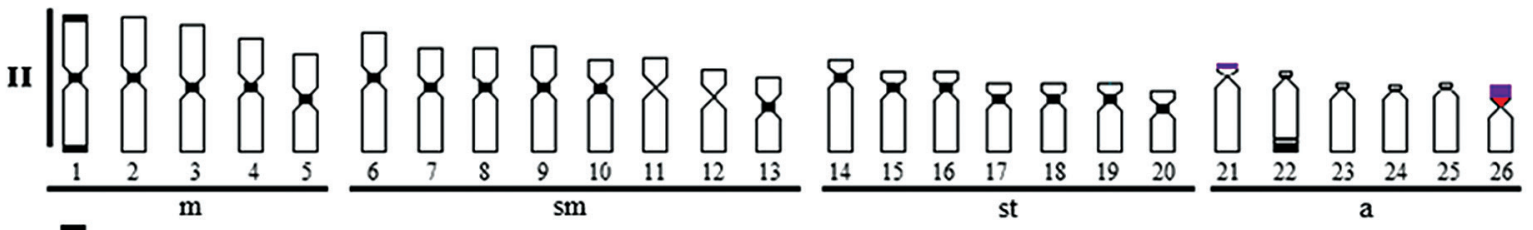

b
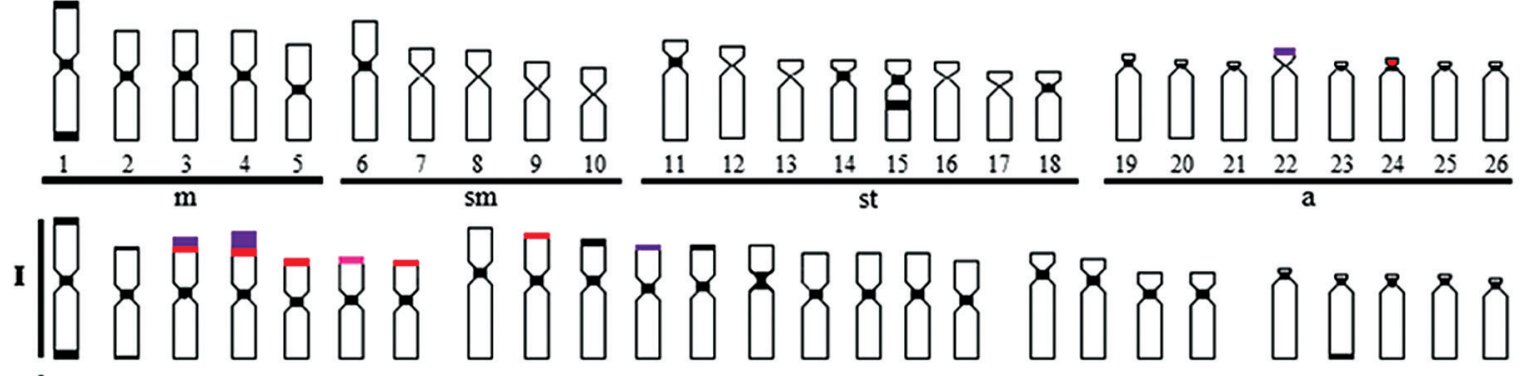

c
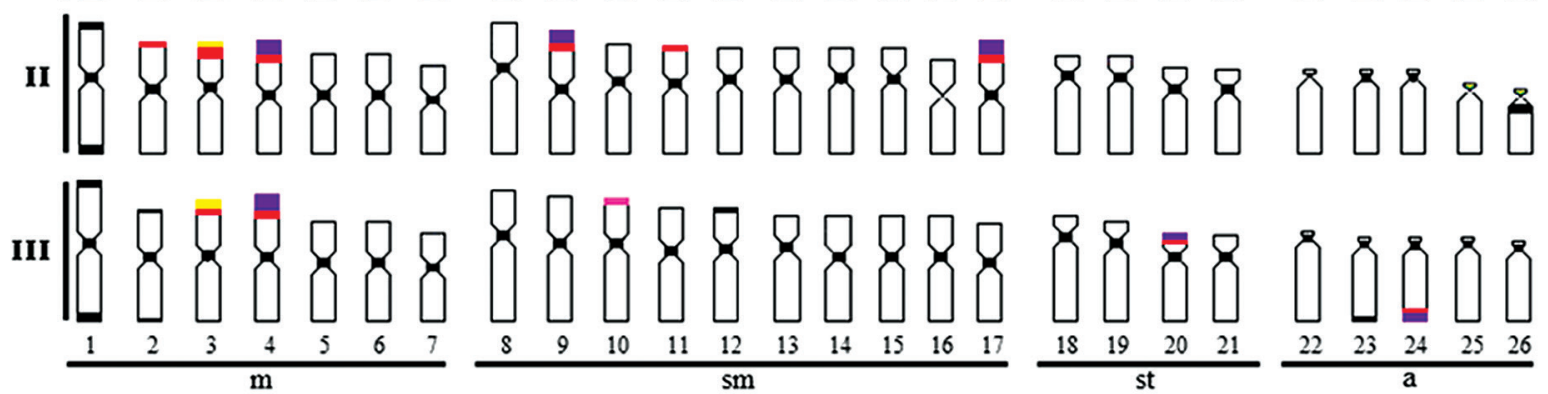

d

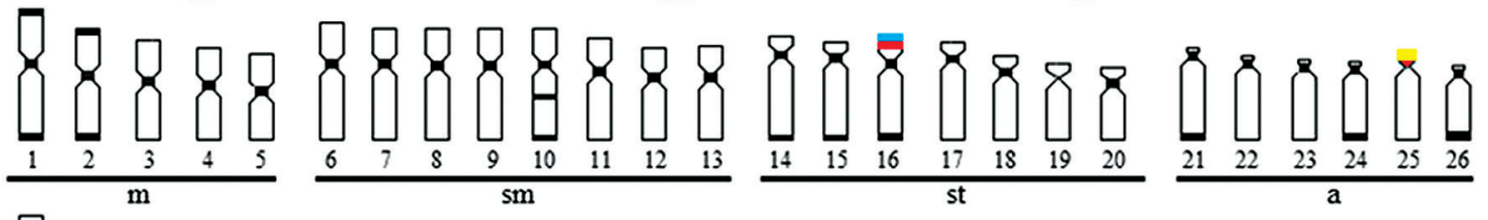

e

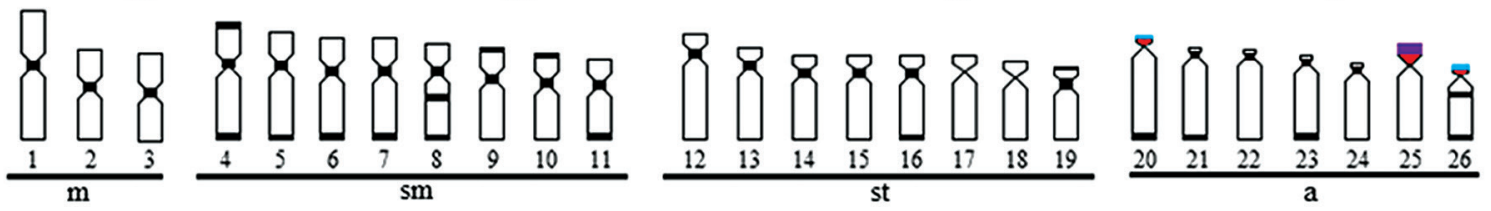

Heterochromatin $\square$ 5S rDNA $\square$ NORs + 18S rDNA + Heterochromatin $\square$ 5S rDNA + Heterochromatin $\square$ 18S rDNA + Heterochromatin $\square$ NORs + 18S rDNA

Fig. 4. Idiogram comparing the cytogenetic characteristics of the four Bryconamericus species. a $B$. aff. iheringii (Ijuí River): patterns I and II; b B. aff. iheringii (Iguaçu River); c B. coeruleus: patterns I, II and II; d B. cf. ecai; e B. cf. eigenmanni.

\section{Discussion}

This study presents the first cytogenetic data for the populations of $B$. aff. iheringii from Ijuí and Iguaçu River, B. coeruleus from Piquiri River, B. cf. ecai and $B$. cf. eigenmanni from Biguá Stream (being the first study for the last). Of the analyzed cytogenetic characters, the fundamental number and the karyotypic formula were effective in the delimitation of the species and in the differentiation of the two populations of $B$. aff. iheringii. The detection of interstitial heterochromatin showed to be a valuable species marker for $B$. cf. ecai (submetacentric pair 10) and B. cf. eigenmanni (submetacentric pair 8 and acrocentric pair 26), as well as a population marker for $B$. aff. iheringii from the Iguaçu River (subtelocentric pairs 15 and 18). The presence of single NORs (confirmed by $18 \mathrm{~S}$ rDNA-FISH) and single 5S rDNA cistrons in individuals of Iguaçu River also differentiated them from $B$. aff. iheringii of Ijuí River. The number and distribution of the $5 \mathrm{~S}-18 \mathrm{~S}$ rDNA cistrons were shown to be relevant marker both for $B$. cf. ecai as in B. cf. eigenmanni.

The cytogenetic studies in Bryconamericus corroborate the diploid number of 52 chromosomes, invariable and considered ancestral for the genus (Wasko, Galetti-Junior, 1998). Added to that is found inter- and intrapopulation/ specific variation for the karyotypic macrostructure and the 
$\mathrm{FN}$, ranging from 80 in cytotype I of $B$. ecai, to 100 in the cytotype IV of B. ecai (Santos et al., 2012), and V and VI of $B$. coeruleus (Silva et al., 2014) (Tab. 2). These characteristics were also verified for all the species analyzed here. According to Wasko, Galetti-Junior (1998), the variation in the FN without the change in the diploid number comprises, in evolutionary terms, the occurrence of chromosomal rearrangements, possibly of the pericentric inversion type, that act in the process of diversification of this group of fish.
It is important to note that what occurs in Bryconamericus differs, for example, from that observed in Astyanax. In this genera the karyotype variation is accompanied by high intra/interspecific and interpopulational divergence of diploid number (Pazza et al., 2018), due to events of fusion and centric fission, often accompanied by inversions and translocations, common in Astyanax spp. (Fernandes, Martins-Santos, 2005; Pazza et al., 2008; Piscor et al., 2019; among others).

Table 2. Review of cytogenetic data in Bryconamericus. $2 \mathrm{n}=$ Diploid number; $\mathrm{FN}=$ Fundamental number; $\mathrm{CB}=\mathrm{C}-\mathrm{b} a n d i n g$, $18 \mathrm{~S}=18 \mathrm{~S}$ rDNA cistrons number; $5 \mathrm{~S}=5 \mathrm{~S}$ rDNA cistrons number; $\mathrm{PR}=$ State of Paraná; $\mathrm{RS}=$ State of Rio Grande do Sul; $\mathrm{SC}=$ State of Santa Catarina; $\mathrm{SP}=$ State of São Paulo; ${ }^{*}$ Cited as $B$. aff. iheringii $; \mathrm{C}=$ Centromeric, $\mathrm{I}=$ Interstitial, $\mathrm{ST}=$ Subterminal, $\mathrm{T}=$ Telomeric, $\mathrm{T}^{*}=$ Terminal.

\begin{tabular}{|c|c|c|c|c|c|c|c|c|c|}
\hline Species & Locality/State & $2 \mathrm{n}$ & Karyotype formula & $\mathrm{FN}$ & $\mathrm{CB}$ & NORs & $18 \mathrm{~S}$ & $5 \mathrm{~S}$ & References \\
\hline B. aff. exodon - I & Três Bocas Stream (PR) & 52 & $16 \mathrm{~m}+12 \mathrm{sm}+6 \mathrm{st}+18 \mathrm{a}$ & 86 & - & $2-5$ & 8 & - & \multirow{2}{*}{$\begin{array}{l}\text { Paintner-Marques et al. } \\
(2002 \mathrm{a}, \mathrm{b})\end{array}$} \\
\hline B. aff. exodon - II & Três Bocas Stream (PR) & 52 & $10 \mathrm{~m}+24 \mathrm{sm}+6 \mathrm{st}+12 \mathrm{a}$ & 92 & - & $2-5$ & 8 & - & \\
\hline B. coeruleus* & Água da Floresta River (PR) & 52 & $8 m+22 s m+10 s t+12 a$ & 92 & $\mathrm{C}, \mathrm{T}$ & 2 & 2 & - & Paintner-Marques et al. (2003) \\
\hline B. coeruleus*- I & Keller River (PR) & 52 & $12 m+18 s m+8 s t+14 a$ & 90 & $\mathrm{P}, \mathrm{T}$ & - & - & - & \multirow{2}{*}{ Portela-Castro et al. (2008) } \\
\hline B. coeruleus*- II & Keller River (PR) & 52 & $8 m+28 s m+6 s t+10 a$ & 94 & $\mathrm{P}, \mathrm{T}$ & - & - & - & \\
\hline B. coeruleus* & Tatupeba Stream (PR) & 52 & $8 m+20 s m+8 s t+16 a$ & 88 & - & 2 & 2 & - & \multirow{3}{*}{ Capistano et al. (2008) } \\
\hline B. coeruleus* & Maringá Stream (PR) & 52 & $12 \mathrm{~m}+18 \mathrm{sm}+8 \mathrm{st}+14 \mathrm{a}$ & 90 & - & $2-4$ & 6 & - & \\
\hline B. coeruleus $*$ & Keller River (PR) & 52 & $8 m+28 s m+6 s t+10 a$ & 94 & - & $2-4$ & 10 & - & \\
\hline B. coeruleus*-I & Três Bocas Stream (PR) & 52 & $12 m+16 s m+10 s t+14 a$ & 90 & - & $3-5$ & - & - & \multirow{4}{*}{ Eberhardt et al. (2012) } \\
\hline B. coeruleus*- II & Três Bocas Stream (PR) & 52 & $14 m+18 s m+10 s t+10 a$ & 94 & - & 2 & - & - & \\
\hline B. coeruleus*- III & Três Bocas Stream (PR) & 52 & $10 \mathrm{~m}+24 \mathrm{sm}+6 \mathrm{st}+12 \mathrm{a}$ & 92 & - & $2-3$ & - & - & \\
\hline B. coeruleus $*$ IV & Três Bocas Stream (PR) & 52 & $10 m+14 s m+8 s t+20 a$ & 84 & - & 0 & - & - & \\
\hline B. coeruleus $*$ - I & Três Bocas Stream (PR) & 52 & $12 m+10 s m+16 s t+14 a$ & 90 & $\mathrm{P}$ & 2 & 2 & - & \multirow{6}{*}{ Silva et al. (2014) } \\
\hline B. coeruleus*- II & Três Bocas Stream (PR) & 52 & $18 \mathrm{~m}+14 \mathrm{sm}+10 \mathrm{st}+10 \mathrm{a}$ & 94 & $\mathrm{P}$ & $2-4$ & $2-6$ & - & \\
\hline B. coeruleus*- III & Três Bocas Stream (PR) & 52 & $20 \mathrm{~m}+18 \mathrm{sm}+4 \mathrm{st}+10 \mathrm{a}$ & 94 & $\mathrm{P}$ & $2-5$ & $2-6$ & - & \\
\hline B. coeruleus*-IV & Três Bocas Stream (PR) & 52 & $20 m+14 s m+12 s t+6 a$ & 98 & $\mathrm{P}$ & $2-3$ & 4 & - & \\
\hline B. coeruleus*-V & Três Bocas Stream (PR) & 52 & $22 \mathrm{~m}+18 \mathrm{sm}+8 \mathrm{st}+4 \mathrm{a}$ & 100 & $\mathrm{P}$ & $3-4$ & $4-6$ & - & \\
\hline B. coeruleus $*-\mathrm{VI}$ & Três Bocas Stream (PR) & 52 & $18 m+24 s m+6 s t+4 a$ & 100 & $\mathrm{P}$ & $3-5$ & $4-6$ & - & \\
\hline B. coeruleus $*$ & Ocoí River (PR) & 52 & $12 m+18 s m+8 s t+14 a$ & 90 & $\mathrm{P}$ & 2 & 2 & - & Nishiyama et al. (2015) \\
\hline B. coeruleus & Piquiri River (PR) & 52 & $14 m+20 s m+8 s t+10 a$ & 94 & $\mathrm{P}, \mathrm{T}$ & $4-5$ & $6-9$ & $10-11$ & Present study \\
\hline$B$. aff. iheringii & Ijuí River (RS) & 52 & $10 \mathrm{~m}+16 \mathrm{sm}+14 \mathrm{st}+12 \mathrm{a}$ & 92 & $\mathrm{P}, \mathrm{ST}, \mathrm{T}^{*}$ & 3 & 3 & $2-4$ & Present study \\
\hline$B$. aff. iheringii & Iguaçu River (PR) & 52 & $10 \mathrm{~m}+10 \mathrm{sm}+16 \mathrm{st}+16 \mathrm{a}$ & 88 & $\mathrm{P}, \mathrm{T}^{*}, \mathrm{I}$ & 2 & 2 & 2 & Present study \\
\hline B. cf. iheringii & Tributary of Corumbataí River (SP) & 52 & $10 \mathrm{~m}+14 \mathrm{sm}+18 \mathrm{st}+10 \mathrm{a}$ & 94 & $\mathrm{P}$ & 2 & 2 & 2 & Piscor et al. (2013) \\
\hline B. ecai - I & Forquetinha River (RS) & 52 & $10 \mathrm{~m}+10 \mathrm{sm}+8 \mathrm{st}+24 \mathrm{a}$ & 80 & $\mathrm{P}, \mathrm{T}$ & $2-4$ & 4 & - & \multirow{4}{*}{ Santos et al. (2012) } \\
\hline B. ecai - II & Forquetinha River (RS) & 52 & $10 m+18 s m+8 s t+16 a$ & 88 & $\mathrm{P}$ & 2 & 2 & - & \\
\hline B. ecai - III & Forquetinha River (RS) & $52+\mathrm{B}$ & $14 m+14 s m+6 s t+18 a$ & 86 & $\mathrm{P}$ & $2-3$ & 6 & - & \\
\hline B. ecai - IV & Forquetinha River (RS) & 52 & $10 m+24 s m+14 s t+4 a$ & 100 & $\mathrm{P}, \mathrm{T}, \mathrm{I}$ & 2 & 2 & - & \\
\hline B. ecai - V & Forquetinha River (RS) & 52 & $8 m+16 s m+14 s t+14 a$ & 90 & - & 3 & 4 & 6 & \multirow{3}{*}{ Santos et al. (2017) } \\
\hline B. ecai - VI & Forquetinha River (RS) & 52 & $10 \mathrm{~m}+16 \mathrm{sm}+8 \mathrm{st}+18 \mathrm{a}$ & 86 & - & 3 & 13 & 8 & \\
\hline B. ecai - VI & Forquetinha River (RS) & 52 & $8 m+18 s m+10 s t+16 a$ & 88 & - & 3 & 10 & 7 & \\
\hline B. cf. ecai & Bigua Stream (SC) & 52 & $10 m+16 s m+14 s t+12 a$ & 92 & $\mathrm{P}, \mathrm{T}^{*}, \mathrm{I}$ & 2 & 4 & 4 & Present study \\
\hline B. cf. eigenmanni & Bigua Stream (SC) & 52 & $6 m+16 s m+16 s t+14 a$ & 90 & $\mathrm{P}, \mathrm{T}^{*}, \mathrm{I}$ & 2 & 4 & 5 & Present study \\
\hline B. turiuba & Tributary of Passa-Cinco River (SP) & 52 & $8 m+10 s m+14 s t+20 a$ & 84 & $\mathrm{P}$ & 2 & 4 & 4 & Piscor et al. (2013) \\
\hline $\begin{array}{l}\text { Bryconamericus. sp. } \\
\text { - Group } 1\end{array}$ & Vermelho River (PR) & 52 & $16 \mathrm{~m}+14 \mathrm{sm}+10 \mathrm{st}+12 \mathrm{a}$ & 92 & - & 2 & 4 & 6 & \multirow{3}{*}{ Santos et al. (2017) } \\
\hline $\begin{array}{l}\text { Bryconamericus. sp. } \\
\text { - Group } 2\end{array}$ & Vermelho River (PR) & 52 & $16 \mathrm{~m}+14 \mathrm{sm}+10 \mathrm{st}+12 \mathrm{a}$ & 92 & - & 5 & 16 & 8 & \\
\hline Bryconamericus sp. & Cambutá River (PR) & 52 & $2 \mathrm{~m}+10 \mathrm{sm}+20 \mathrm{st}+20 \mathrm{a}$ & 88 & - & 3 & 6 & 2 & \\
\hline
\end{tabular}


The two populations of $B$. aff. iheringii analyzed presented different karyotypic macrostructure among themselves and compared to other populations of the same species. Likewise, $B$. cf. ecai differed from other populations already studied (Santos et al., 2012, 2017). This indicates a high degree of chromosomal rearrangements, common in other Stevardiinae genera such as Piabina (Fernandes et al., 2010; Pazian et al., 2012; Piscor et al., 2018) and Piabarchus (Fernandes et al., 2010, cited as Bryconamericus), and in other complex groups of Characidae, such as the Serrasalmus (Martins-Santos et al., 1994; Centofante et al., 2002), Cheirodon (Soto et al., 2018) and Astyanax (Yano et al., 2014; Paiz et al., 2015; Nishiyama et al., 2016, among others).

Cytogenetic studies in Bryconamericus by PaintnerMarques et al. (2003) have involved the detection of heterochromatic regions through $\mathrm{C}$-banding, revealing relevant characteristics in comparative analyzes. In the species analyzed here, the predominance of heterochromatin in the pericentromeric region of most chromosomes was obseerved, a common pattern for the genus, but with variation in chromosomes with interstitial, subterminal and terminal heterochromatin. Conspicuous heterochromatic blocks in the interstitial region of chromosomes were found only in cytotype IV of B. ecai (Santos et al., 2012), and in the present study in $B$. aff. iheringii (Iguaçu River), B. cf. ecai and $B$. cf. eigenmanni (Figs. 2, 4b, d, e), allowing to distinguish these species among themselves and to differentiate the two populations of $B$. aff. iheringii. In $B$. aff. iheringii from the Ijuí River, the presence of subterminal heterochromatins on a pair of acrocentric chromosomes was observed in both patterns, revealing that this is a conserved characteristic in the population, and also allows distinguishing it from the population of the Iguaçu River. The B. coeruleus pattern II differed from the others by the presence of a pericentromeric/ interstitial heterochromatic block on the long arm of the last pair of acrocentric chromosomes (Fig. 4c-II).

The number of chromosomes pairs with terminal heterochromatin also made it possible to differentiate the species and populations of Bryconamericus (Figs. 2, 4), with the exception of terminal heterochromatin located in both arms on the metacentric chromosome pair 1, which were shared by all species and patterns found, except in $B$. cf. eigenmanni. In this species, the same pattern of heterochromatin was evidenced in the first pair of submetaccentric chromosomes (pair 4), suggesting that these chromosomes may have been metacentric chromosomes that underwent pericentric inversion, so that all possibly share the same sequences in these regions. As proposed by Wasko, Galetti-Junior (1998), the Bryconamericus species do not seem to reveal a general trend in relation to the heterochromatin distribution, so that each species can be characterized by a specific C-band pattern, as also observed by Piscor et al. (2013) and in the present study. However, the variation in the distribution of these regions is also visible at interpopulation (Portela-Castro et al., 2008; present study) and intrapopulation levels (Santos et al., 2012; present study, in $B$. aff. iheringii from the Ijuí River and in $B$. coeruleus, especially regarding heterochromatins associated with NORs).

Although silver impregnation revealed single NORs in three species of this study (Fig. 1b, d, e, boxes), 18S rDNAFISH confirmed single sites only in $B$. aff. iheringii (Iguaçu River) (Figs. 1, 4b, d, e). Bryconamericus aff. iheringii from the Ijuí River exhibited two patterns of multiple NORs, both with three chromosomes bearing these regions (Figs. 1, 4a), whereas in B. coeruleus it was possible to identify three distinct patterns (pattern I: five bearing chromosomes; patterns II and III: four bearing chromosomes) (Figs. $1,4 \mathrm{c})$. The presence of single NORs is less recurrent in Bryconamericus than the occurrence of multiple NORs, as evidenced in Table 2. According to Machado et al. (2017), the presence of multiple $18 \mathrm{~S}$ rDNA sequences dispersed in the genome may reflect the amplification and dispersion of these genes mediated by their association with mobile genetic elements (transposons and/or retrotransposons).

The analysis of the chromosomes carrying the NORs allows the diagnosis of intra-individual heteromorphism of region size between the homologous chromosomes in $B$. aff. iheringii from the Iguaçu River, $B$. coeruleus (patterns I and III: pair 4; pattern II: pair 9), and B. cf. ecai of the present study (Fig. 1b, c, d). These data were confirmed by $18 \mathrm{~S}$ rDNA-FISH, revealing that in these species there is, in fact, variation in the number of copies of this ribosomal gene, due to events of duplication or deletion occurred during meiosis. Similar considerations were made by Piscor et al. (2013) in B. cf. iheringii, and Santos et al. (2017) in Bryconamericus sp. (Group 1), but in both cases 18S rDNA-FISH detected sites of similar size, indicating that the variation visualized by silver impregnation could refer to differences in the degree of condensation between homologous chromosomes, and differential gene activity rDNA segments (45S).

The 5S rDNA-FISH revealed the presence of these genes always in the terminal region of the chromosomes, varying between single sites in $B$. aff. iheringii from the Iguaçu River and pattern II of the Ijuí River population (Figs. 3, 4a, b), and multiple sites in pattern I of this population and in the other species analyzed. With the exception of $B$. aff. iheringii from the Iguaçu River, the other species and the other population presented 5S rDNA sites located in the short arm of pairs bearing $18 \mathrm{~S}$ rDNA genes, configuring the syntenic location. Data for $5 \mathrm{~S}$ rDNA are scarce for the genus, and are restricted to some populations of $B$. cf. iheringii, B. turiuba, B. ecai and Bryconamericus sp. (Piscor et al., 2013; Santos et al., 2017), revealing a variation in the number and location of these cistrons, as well as the frequent sinteny to $18 \mathrm{~S}$ rDNA genes, as verified in the species of the present study. The $5 \mathrm{~S}-18 \mathrm{~S}$ rDNA syntenic localization has also been reported in other groups, such as Prochilodus lineatus (Valenciennes, 1837) (Vicari et al., 2006), Hypostomus commersoni Valenciennes, 1836 (Bueno et al., 2014), Astyanax altiparanae Garutti \& Britski, 2000, Astyanax lacustris (Lütken, 1875), Astyanax 
fasciatus (Cuvier, 1819), Astyanax schubarti Britski, 1964 and Astyanax paranae Eigenmann, 1914 cited as Astyanax scabripinnis (Jenyns, 1842) (Almeida-Toledo et al., 2002), Solea senegalensis Kaup, 1858 (Cross et al., 2006), and Corydoras carlae Nijssen \& Isbrücker, 1983 (Rocha et al., 2016) and marine species Thalassoma noronhanum (Boulenger, 1890), Halichoeres penrosei Starks, 1913, H. poeyi (Steindachner, 1867), H. radiatus (Linnaeus, 1758) and H. brasiliensis (Bloch, 1791) (Amorim et al., 2016).

The ribosomal DNA genes in eukaryotes comprise two multigenic families: 45S rDNA, transcribed in the nucleolus, and 5S rDNA, transcribed outside the nucleolus, suggesting that the differential functioning of both families requires physical detachment (Martins, Galetti-Junior, 2001), avoiding the occurrence of disruptive interferences, such as translocations from $5 \mathrm{~S}$ to $45 \mathrm{~S}$ and vice-versa, capable of affecting the dynamics of both (Martins, GalettiJunior, 1999). On the other hand, as the double-FISH techniques have been performed, the greater the number of fish species with a syntenic location of these sequences. According to Schweizer, Loidl (1987), the telomeric regions are susceptible to equi-local transfers, even between nonhomologous chromosomal arms, according to their proximity in the interphase nucleus promoted by the orientation of the chromosomes according to the Rabl model. Thus, we can infer that in all species analyzed in this work (except $B$. aff. iheringii from the Iguaçu River that did not display sinteny), the transfer events between the two multigenic families may have been facilitated.

The large variation in the number of $5 \mathrm{~S}$ rDNA cistrons, especially in B. coeruleus, may suggest the occurrence of pseudogeneization events or the insertion of mobile genetic elements in the 5S rDNA intergenic spacers, promoting the detection of "extra" sites of this gene through FISH, in addition to those effectively functional, as observed in Erythrinus erythrinus (Bloch \&Schneider, 1801) (Cioffi et al., 2010) and Gymnotus mamiraua Albert \& Crampton, 2001 (Silva et al., 2016).

The cytogenetic data of this study (diploid number, karyotype formulas and the fundamental numbers) corroborate the hypothesis of the occurrence of chromosomal rearrangements, possibly pericentric inversions. That demonstrate the complexity involved in the evolutionary dynamics of the group and, although Bryconamericus does not present a general trend of heterochromatin distribution, specific heterochromatic blocks proved to be important cytogenetic markers in the identification of some species and in the differentiation of the two analyzed populations. The dispersed location of ribosomal genes (5S-18S rDNA) suggests the occurrence of amplifications of these sequences, associated with events of duplication, pseudogeneization and transposition mediated by mobile genetic elements, and their co-localization in all species may represent a plesiomorphic condition in Bryconamericus, although this group lacks cytogenetic and molecular data to better understand the evolutionary dynamics of these genes.

\section{Acknowledgments}

The authors are thankful to the Instituto Chico Mendes de Conservação da Biodiversidade (MMA/ICMBio) for authorizing fish captures (License number: SISBIO 10522-1). Thanks are given to the Universidade Estadual do Oeste do Paraná (UNIOESTE), Parque Nacional do Iguaçu, Macuco Safari and Núcleo de Pesquisas em Limnologia, Ictiologia e Aquicultura (Núpelia) for logistical support. This study was financed by CAPES (Coordenadoria de Aperfeiçoamento de Ensino Superior), $\mathrm{CNPq}$ (Conselho Nacional de Desenvolvimento Científico e Tecnológico) and FPTI (Fundação Parque Tecnológico Itaipu). This study was carried out in strict accordance with the recommendations of the Guide for the Care and Use of Laboratory Animals, approved by the Committee on the Ethics of Animal Experiments of the Universidade Estadual do Oeste do Paraná (License Number: Protocol 13/09 - CEEAAP/Unioeste).

\section{References}

Almeida-Toledo LF, Ozouf-Costaz C, Foresti F, Bonillo C, PortoForesti F, Daniel-Silva MFZ. Conservation of the 5S bearing chromosome pair and co-localization with major rDNA clusters in five species of Astyanax (Pisces, Characidae). Cytogenet Genome Res. 2002; 97(3-4):229-33. https://doi. org/10.1159/000066609

Amorim KDJ, Cioffi MB, Bertollo LAC, Soares RX, Souza AS, Costa GWWF, Molina WF. Co-located 18S/5S rDNA arrays: an ancient and unusual chromosomal trait in Julidini species (Labridae, Perciformes). Comp Cytogenet. 2016; 10(4):55570. https://doi.org/10.3897/CompCytogen.v10i4.10227

Bertollo LAC, Takahashi CS, Moreira-Filho O. Cytotaxonomic considerations on Hoplias lacerdae (Pisces, Erythrinidae). Rev Bras Genet. 1978; 1(2):103-20.

Bueno V, Venere PC, Konerat JT, Zawadzki CH, Vicari MR, Margarido VP. Physical mapping of the 5S and 18S rDNA in ten species of Hypostomus Lacépède 1803 (Siluriformes: Loricariidae): evolutionary tendencies in the genus. Sci World J. 2014; 2014(1):1-8. http://dx.doi.org/10.1155/2014/943825

Capistano TG, Portela-Castro ALB, Julio-Jr. HF. Chromosome divergence and NOR polymorphism in Bryconamericus aff. iheringii (Teleostei, Characidae) in the hydrographic systems of the Paranapanema and Ivaí Rivers, Paraná, Brazil. Genet Mol Biol. 2008; 31(1):203-07. http://dx.doi.org/10.1590/ S1415-47572008000200006

Centofante L, Porto JIR, Feldberg E. Chromosomal polymorphism in Serrasalmus spilopleura Kner, 1858 (Characidae, Serrasalminae) from Central Amazon Basin. Caryologia G Citol Citosistematica Citogenet. 2002; 55(1):37-45. https:// doi.org/10.1080/00087114.2002.10589256

Cioffi MB, Martins C, Bertollo LAC. Chromosomal spreading of associated transposable elements and ribosomal DNA in the fish Erythrinus erythrinus. Implications for genome change and karyoevolution in fish. BMC Evol Biol. 2010; 10(271):19. https://doi.org/10.1186/1471-2148-10-271 
Cross I, Merlo A, Manchado M, Infante C, Cañavate P, Rebordinos L. Cytogenetic characterization of the sole Solea senegalensis: AgNOR, (GATA), (TTAGGG) $)_{n}$ and ribosomal genes by one-color and two-color FISH. Genetica. 2006; 128(1-3):253-59. https:// doi.org/10.1007/s10709-005-5928-9

Eberhardt GN, Silva LLL, Santos AR, Dias AL. Occurrence of cytotypes and variability of AgNORs in a population of Bryconamericus aff. iheringii (Characidae). Cytologia. 2012; 77(4):507-13. https://doi.org/10.1508/cytologia.77.507

Fernandes CA, Martins-Santos IC. Sympatric occurrence of three cytotypes and four morphological types of B chromosomes of Astyanax scabripinnis (Pisces, Characiformes) in the River Ivai Basin, state of Paraná, Brazil. Genetica. 2005; 124(2-3):301-06. https://doi.org/10.1007/s10709-005-4751-7

Fernandes CA, Piscor D, Bailly D, Silva VFB, Martins-Santos IC. Cytogenetic studies comparing three Characidae fish species from the Iguatemi River Basin, Brazil. Cytologia. 2010; 75(4):329-33. https://doi.org/10.1508/cytologia.75.329

Fricke R, Eschmeyer WN, Van Der Laan R. Eschmeyer's catalog of fishes: genera, species, references [Internet]. San Francisco: California Academy of Sciences; 2019. Available from: http:// researcharchive.calacademy.org/research/ichthyology/catalog/ fishcatmain.asp.

Géry J. Characoids of the World. New Jersey: T.F.H. Publications Inc.; 1977.

Griffiths SP. The use of clove oil as an anaesthetic and method for sampling interdidal rockpool fishes. J Fish Biol. 2000; 57(6): 1453-64. https://doi.org/10.1111/j.1095-8649.2000.tb02224.x

Hatanaka T, Galetti-Junior PM. Mapping of the 18S and 5S ribosomal RNA genes in the fish Prochilodus argenteus Agassiz, 1829 (Characiformes, Prochilodontidae). Genetica. 2004; 122(3):23944. https://doi.org/10.1007/s10709-004-2039-y

Howell WM, Black DA. Controlled silver-staining of nucleolus organizer regions with a protective colloidal developer: a 1-step method. Cell Mol Life Sci. 1980; 36(8):1014-15.

Javonillo R, Malabarba LR, Weitzman SH, Burns J. Relationships among major lineages of characid fishes (Teleostei: Ostariophysi: Characiformes), based on molecular sequence data. Mol Phylogenet Evol. 2010; 54(1):498-511. https://doi.org/10.1016/j. ympev.2009.08.026

Jerep FC, Shibatta OA. A new species of Bryconamericus (Characidae: Stevardiinae: Diapomini) from the upper rio Paraná basin, Brazil. Neotrop Ichthyol. 2017; 15(3):e170028. Available from: http://dx.doi.org/10.1590/1982-0224-20170028

Levan A, Fredga K, Sandberg AA. Nomenclature for centromeric position on chromosomes. Hereditas. 1964; 52(2):201-20. https://doi.org/10.1111/j.1601-5223.1964.tb01953.x

Lima FCT, Malabarba LR, Buckup PA, Silva JFP, Vari RP, Harold A, Benine R, Oyakawa OT, Pavanelli CS, Menezes NA. Genera Incertae Sedis in Characidae. In: Reis RE, Kullander SO, Ferraris CJ, Jr., editors. Check List of the Freshwater Fishes of the South and Central America. Porto Alegre: Edipucrs; 2003. p.106-69.

Lui RL, Blanco DR, Moreira-Filho O, Margarido VP. Propidium iodide for making heterochromatin more evident in the C-banding technique. Biotech Histochem. 2012; 87(7):433-38. https://doi.or g/10.3109/10520295.2012.696700
Machado MA, Cardoso AL, Milhomem-Paixão SSR, Pieczarka JC, Nagamachi CY. Gymnotus coatesi (Gymnotiformes): A case of colocation of multiple sites of $18 \mathrm{~S}$ rDNA with Telomeric Sequences. Zebrafish. 2017; 14(5):459-63. http://doi. org/10.1089/zeb.2017.1435

Malabarba LR, Weitzman SH. Description of a new genus with six new species from southern Brazil, Uruguay and Argentina, with a discussion of a putative Characid clade (Teleostei: Characiformes: Characidae). Comun Mus Ciênc Tecnol Ser Zool. 2003; 16(1):67-151.

Margarido VP, Moreira-Filho O. Karyotypic differentiation through chromosome fusion and number reduction in Imparfinis hollandi (Ostariophysi, Heptapteridae). Genet Mol Biol. 2008; 31(1): 235-38. http://dx.doi.org/10.1590/S1415-47572008000200012

Martins C, Galetti-Junior PM. Chromosomal localization of $5 \mathrm{~S}$ rDNA genes in Leporinus fish (Anostomidae, Characiformes). Chromosome Res. 1999; 7(5):363-67. https://doi. org/10.1023/A:1009216030316

Martins C, Galetti-Junior PM. Two 5S rDNA arrays in Neotropical fish species: is it a general rule for fishes?. Genetica. 2001; 111(1-3):439-46. https://doi.org/10.1023/A:1013799516717

Martins-Santos IC, Júlio-Jr HF, Santos SJ. Chromosome study of two species of the genus Serrasalmus (Characidae, Serrasalminae) from the Parana River. Cytologia. 1994; 59(1):175-81. https:// doi.org/10.1508/cytologia.59.175

Mirande JM. Weighted parsimony phylogeny of the family Characidae (Teleostei: Characiformes). Cladistics. 2009; 25(6):574-613. http://doi.org/10.1111/j.1096-0031.2009.00262.x

Mirande JM. Phylogeny of the family Characidae (Teleostei: Characiformes): from characters to taxonomy. Neotrop Ichthyol. 2010; 8(3):385-568. http://dx.doi.org/10.1590/S167962252010000300001

Mirande JM. Morphology, molecules and the phylogeny of Characidae (Teleostei, Characiformes). Cladistics. 2018; 35(3):282-300. http://doi.org/10.1111/cla.12345

Nishiyama PB, Vieira MMR, Porto FE, Borin LA, Portela-Castro ALB, Santos ICM. Karyotypic diversity among three species of the genus Astyanax (Characiformes: Characidae). Braz J Biol. 2016; 76(2):360-66. http://dx.doi.org/10.1590/15196984.15414

Oliveira C, Avelino GS, Abel KT, Mariguela TC, Benine RC, Ortí G, Vari RP, Corrêa e Castro RM. Phylogenetic relationships within the speciose family Characidae (Teleostei: Ostariophysi: Characiformes) based on multilocus analysis and extensive in group sampling. BMC Evol Biol. 2011; 11(275):1-25. https:// doi.org/10.1186/1471-2148-11-275

Paintner-Marques TRP, Giuliano-Caetano L, Dias AL. Karyotypic diversity in a Bryconamericus aff. exodon population (Characidae, Tetragonopterinae). Cytologia. 2002a; 67(4):397402. https://doi.org/10.1508/cytologia.67.397

Paintner-Marques TRP, Giuliano-Caetano L, Dias AL. Multiple NORs in Bryconamericus aff. exodon (Osteichthyes, Characidae, Tetragonopterinae). Hereditas. 2002b; 137(2):107-12. https:// doi.org/10.1034/j.1601-5223.2002.01651.x

Paintner-Marques TRP, Giuliano-Caetano L, Dias AL. Cytogenetic characterization of a population of Bryconamericus aff. 
iheringii (Characidae, Tetragonopterinae). Genet Mol Biol. 2003; 26(2):145-49. http://dx.doi.org/10.1590/S141547572003000200007

Paiz LM, Baumgärtner L, Graça WJ, Margarido VP. Basic cytogenetics and physical mapping of ribosomal genes in four Astyanax species (Characiformes, Characidae) collected in Middle Paraná River, Iguassu National Park: considerations on taxonomy and systematics of the genus. Comp Cytogenet. 2015; 9(1):51-65. https://dx.doi.org/10.3897\%2FCompCytogen. v9i1.9002

Pazian MF, Pereira LHG, Shimabukuru-Dias CK, Oliveira C, Foresti F. Cytogenetic and molecular markers reveal the complexity of the genus Piabina Reinhardt, 1867 (Characiformes: Characidae). Neotrop Ichthyol. 2012; 10(2):329-40. http:// dx.doi.org/10.1590/S1679-62252012005000015

Pazza R, Kavalco SAF, Penteado PR, Kavalco KF, Almeida-Toledo LF. The species complex Astyanax fasciatus Cuvier, 1819 (Teleostei, Characiformes) a multidisciplinary approach. J Fish Biol. 2008; 72(8):2002-10. https://doi.org/10.1111/j.10958649.2008.01837.x

Pazza R, Dergam JA, Kavalco KF. Trends in Karyotype in Astyanax (Teleostei, Characiformes, Characidae): insights from molecular data. Front Genet. 2018; 9(131):1-11. https://doi.org/10.3389/ fgene.2018.00131

Pinkel D, Straume T, Gray JW. Cytogenetic analysis using quantitative, high sensitivity, fluorescence hybridization. Proc Natl Acad Sci USA. 1986; 83(9):2934-38. https://doi. org/10.1073/pnas.83.9.2934

Piscor D, Fernandes CA, Parise-Maltempi PP. Conserved number of U2 snDNA sites in Piabina argentea, Piabarchus stramineus and two Bryconamericus species (Characidae, Stevardiinae). Neotrop Ichthyol. 2018; 16(1):1-7. http://dx.doi.org/10.1590/1982-022420170066

Piscor D, Pozzobon APB, Fernandes CA, Centofante L, PariseMaltempi PP. Molecular clock as insight to estimate the evolutionary history and times of divergence for 10 nominal Astyanax species (Characiformes, Characidae): an evolutionary approach in species with $2 \mathrm{n}=36,46,48$ and 50 chromosomes. Zebrafish. 2019; 16(1):98-105. https://doi.org/10.1089/ zeb.2018.1647

Piscor D, Ribacinco-Piscor DB, Fernandes CA, Parise-Maltempi PP. Cytogenetic analysis in three Bryconamericus species (Characiformes, Characidae): first description of the 5S rDNAbearing chromosome pairs in the genus. Mol Cytogenet. 2013; 6(13):1-8. https://doi.org/10.1186/1755-8166-6-13

Portela-Castro ALB, Julio-Jr. HF, Santos ICM, Pavanelli CS. Occurrence of two cytotypes in Bryconamericus aff. iheringii (Characidae): karyotype analysis by $\mathrm{C}$ - and G-banding and replication bands. Genetica. 2008; 133(2):113-18.

Rocha RH, Baumgärtner L, Paiz LM, Margarido VP, Fernandes CA, Gubiani EA. An uncommon co-localization of rDNA 5S with major rDNA cluster in Callichthyidae (Siluriformes): a report case in Corydoras carlae Nijssen \& Isbrücker, 1983. Comp Cytogenet. 2016; 10:603-13. https://dx.doi. org/10.3897\%2FCompCytogen.v10i4.9507
Santos AR, Rubert M, Giuliano-Caetano L, Dias AL. Sympatric occurrence of four cytotypes and one extra chromosome in Bryconamericus ecai (Characidae): 18S rDNA polymorphism and heterochromatin composition. Hereditas. 2012; 149(1):2433. https://doi.org/10.1111/j.1601-5223.2011.02234.x

Santos AR, Usso MC, Gouveia JG, Araya-Jaime C, Frantine-Silva W, Giuliano-Caetano L, Foresti F, Dias AL. Chromosomal Mapping of repetitive DNA sequences in the genus Bryconamericus (Characidae) and DNA barcoding to differentiate populations. Zebrafish. 2017; 14(3):261-71. https://doi.org/10.1089/ zeb.2016.1380

Schweizer D, Loidl JA. Model for heterochromatin dispersion and the evolution of C-band patterns. In: Stahl A, Luciani JM, Vagner-Capodano A, editors. Chromossomes Today. Dorddrecht: Springer; 1987. p.61-74.

Silva LLL, Giuliano-Caetano L, Dias AL. Karyotypic diversity in a population of Bryconamericus aff. iheringii (Characidae). Genet Mol Res. 2014; 13(1):2069-81. http://dx.doi.org/10.4238/2014. March.24.11

Silva M, Barbosa P, Artoni RF, Feldberg E. Evolutionary dynamics of $5 \mathrm{~S}$ rDNA and recurrent association of transposable elements in electric fish of the family Gymnotidae (Gymnotiformes): the case of Gymnotus mamiraua. Cytogenet Genome Res. 2016; 149(4):297-303. https://doi.org/10.1159/000449431

Soto MA, Castro JP, Walker LI, Malabarba LR, Santos MH, Almeida MC, Moreira-Filho O, Artoni RF. Evolution of trans-Andean endemic fishes of the genus Cheirodon (Teleostei: Characidae) are associated with chromosomal rearrangements. Rev Chil de Hist Nat. 2018; 91(8):1-8. https://doi.org/10.1186/s40693-018-0078-5

Sumner AT. A simple technique for demonstrating centromeric heterochromatin. Exp Cell Res. 1972; 75(1):304-06.

Thomaz AT, Arcila D, Ortí G, Malabarba LR. Molecular phylogeny of the subfamily Stevardiinae Gill, 1858 (Characiformes: Characidae): classification and the evolution of reproductive traits. BMC Evol Biol. 2015; 15(1):1-25. http://dx.doi. org/10.1186/s12862-015-0489-8

Vicari MR, Almeida MC, Bertollo LAC, Moreira-Filho O, Artoni RF. Cytogenetic analysis and chromosomal characteristics of the polymorphic $18 \mathrm{~S}$ rDNA in the fish Prochilodus lineatus (Characiformes, Prochilodontidae). Genet Mol Biol. 2006; 29(4):621-25. http://dx.doi.org/10.1590/S141547572006000400008

Wasko AP, Galetti-Junior PM. Karyotype diversity in the neotropical fish Bryconamericus (Characidae, Tetragonopterinae). Cytobios. 1998; 94:185-93.

Yano CF, Moreira-Filho O, Margarido VP. Interpopulational comparative cytogenetics analysis among three Astyanax (Characiformes: Incertae Sedis) species of two streams of upper Paraná River basin, Brazil. Biologia. 2014; 69(6):790-98. https:// doi.org/10.2478/s11756-014-0366-8

Submmited June 6, 2019 Accepted August 6, 2019 by Claudio Oliveira 